\title{
Effect of Foliar Application of Zinc and Manganese on Growth Parameters and Yield of Potato (Solanum tuberosum L.)
}

\author{
Madhukar Singh ${ }^{1}$, Alok Kumar ${ }^{2 *}$, Sanjay Kumar Tripathi ${ }^{3}$, \\ Subhash Kumar ${ }^{3}$ and A. K. Singh ${ }^{1}$ \\ ${ }^{1}$ Department of Crop Physiology, NDUA\&T, Faizabad U.P, India \\ ${ }^{2}$ Department of Seed Science \& Technology, CSAUA\&T, Kanpur U.P, India \\ ${ }^{3}$ Department of Crop Physiology, CSAUAT, Kanpur U.P, India
}

*Corresponding author

\section{Keywords}

Foliar application,

Zinc and

Manganese, Growth parameters, Yield and Potato

\section{Article Info}

Accepted:

10 June 2018

Available Online:

10 July 2018

\section{A B S T R A C T}

In order to study "(Effect of basal and foliar application of $\mathrm{Zn}$ and $\mathrm{Mn}$ on growth parameters and yield of Potato (Solanum tuberosum L.)" cv. Kufri Ashoka was carried out at Main Experiment Station, Department of Vegetable Science, Narendra Deva University of Agriculture \& Technology, Kumarganj, Faizabad (U.P.), during rabi season in the year 2015-16. The soil of experimental field was sandy loam, with low in nitrogen and high in phosphorus and medium in potassium contents. The nine treatments $\mathrm{T}_{1}-(\mathrm{N}: \mathrm{P}: \mathrm{K}) 120$ : $80: 150 \mathrm{~kg} \mathrm{ha}^{-1}$ as basal, $\mathrm{T}_{2}-120: 80: 150: 25$ (N:P:K:Zn) $\mathrm{kg} \mathrm{ha}^{-1}$ as basal, $\mathrm{T}_{3}-$ 120:80:150:25 (N:P:K:Mn) kg/ha ${ }^{-1}$ as basal, $\mathrm{T}_{4}-\mathrm{RDF}+$ Zinc sulphate $\left(\mathrm{ZnSO}_{4}\right) 100 \mathrm{ppm}$ as foliar, $\mathrm{T}_{5}-\mathrm{RDF}+\mathrm{Zinc}$ sulphate $\left(\mathrm{ZnSO}_{4}\right) 200 \mathrm{ppm}$ as foliar, $\mathrm{T}_{6}-\mathrm{RDF}+\mathrm{Zinc}$ sulphate $\left(\mathrm{ZnSO}_{4}\right) 300 \mathrm{ppm}$ as foliar, $\mathrm{T}_{7}-\mathrm{RDF}+$ Manganese sulphate $\left(\mathrm{MnSO}_{4}\right) 100 \mathrm{ppm}$ as foliar, $\mathrm{T}_{8}-\mathrm{RDF}+$ Manganese sulphate $\left(\mathrm{MnSO}_{4}\right) 200 \mathrm{ppm}$ Foliar, $\mathrm{T}_{9}-\mathrm{RDF}+$ Manganese sulphate $\left(\mathrm{MnSO}_{4}\right) 300 \mathrm{ppm}$ as foliar were evaluated in Randomized Block Design with three replications. Observation on various parameters viz. Maximum emergence percentage (93.65), plant height $(43.14 \mathrm{~cm})$, number of haulms per plant (6.40), number of leaves per plant (55.27), fresh weight of plant $(340.23 \mathrm{~g})$, dry weight of plant $(26.35 \mathrm{~g})$, Total number of tuber per plant (8.00), Weight of tuber per plant $(435.12 \mathrm{~g}$ ), yield of tuber (26.98kg), during 2015-16 respectively, were noted maximum with the foliar application of $\mathrm{T}_{6}-\mathrm{RDF}+\mathrm{Zinc}$ sulphate $\left(\mathrm{ZnSO}_{4}\right) 300 \mathrm{ppm}$ as foliar. The experimental findings revealed that the treatment $\mathrm{T}_{6}-\mathrm{RDF}+\left(\mathrm{ZnSO}_{4}\right) 300 \mathrm{ppm}$ as foliar showed better response on plant growth, yield attributes and quality. However, the maximum yield $(26.98 \mathrm{~kg})$ was obtained with the application of $\mathrm{T}_{6}-\mathrm{RDF}+\left(\mathrm{ZnSO}_{4}\right) 300 \mathrm{ppm}$ as foliar.

\section{Introduction}

Foliar application of zinc and manganese has become an efficient way to increase yield and quality of crops. Zinc ( $\mathrm{Zn})$ is known to have an important role either as a metal component of enzymes or as a functional, structural or regulatory co-factor of a large number of enzymes (Grotz and Guerinot, 2006). Manganese (Mn) in turn, is regarded as an 
activator of many different enzymatic reactions and takes part in photosynthesis. Manganese activates decarboxylase and dehydrogenase and is a constituent of complex PSII-protein, SOD and phosphatase. Several researches indicated a positive influence of micronutrient ( $\mathrm{Zn}, \mathrm{Mn}$ ) application in increase of yield and quantitative parameters of crops (Mosavi et al., 2007) on potato.

The aim of this study was to evaluate the effect of foliar application of Zinc and Manganese on growth parameters and yield of Potato (Solanum tuberosum L.) and select out of the best treatment doses in terms of yield and growth parameters.

\section{Materials and Methods}

The present investigation was carried out in Rabi season, during 2015-2016 at the Vegetable Research Station Narendra Deva University of Agriculture and Technology, Kumarganj, Faizabad (U.P.) India.

\section{Details of the treatments}

In order to facilitate their reference the symbol assigned to different treatments are given as under:

$\mathrm{T}_{1}$ : Recommended dose of N:P:K @ 120:80:150 kg ha ${ }^{-1}$ as basal Control

$\mathrm{T}_{2}$ : R.D.F+ $\mathrm{ZnSO}_{4} @ 25 \mathrm{~kg} \mathrm{ha}^{-1}$ as basal at the time of planting

$\mathrm{T}_{3}$ : R.D.F $+\mathrm{MnSO}_{4} @ 25 \mathrm{~kg} \mathrm{ha}^{-1}$ as basal at the time of planting

$\mathrm{T}_{4}$ : R.D.F as basal $+\mathrm{ZnSO}_{4}, 100 \mathrm{ppm}$ as foliar at 50 days after planting

$\mathrm{T}_{5}$ : R.D.F as basal $+\mathrm{ZnSO}_{4}, 200 \mathrm{ppm}$ as foliar at 50 days after planting

$\mathrm{T}_{6}$ : R.D.F as basal $+\mathrm{ZnSO}_{4}, 300 \mathrm{ppm}$ as foliar at 50 days after planting

$\mathrm{T}_{7}$ : R.D.F as basal $+\mathrm{MnSO}_{4}, 100 \mathrm{ppm}$ as foliar at 50 days after planting

$\mathrm{T}_{8}$ : R.D.F as basal $+\mathrm{MnSO}_{4}, 200$ ppm as foliar at 50 days after planting
$\mathrm{T}_{9}$ : R.D.F as basal $+\mathrm{MnSO}_{4}, 300 \mathrm{ppm}$ as foliar at 50 days after planting

The different observations were recorded on Emergence percentage (\%), Plant height $(\mathrm{cm})$, Number of haulms per plant, Number of leaves per plant, Fresh weight of plant (g), Dry weight of plant $(\mathrm{g})$, Total number of tubers per plant, Weight of tuber plant per plant $(\mathrm{g})$ and Total yield of tubers per plot $\left(\mathrm{kg} \mathrm{q}^{-1}\right)$. The various statistical techniques were used for calculation of the data as suggested by Fisher and Yates (1949). The experiment was conducted in randomized block design (RBD) for field experiment.

\section{Results and Discussion}

The application of foliar and basal doses of zinc sulphate and manganese sulphate, time of application and its combination with recommended dose of fertilizers $\mathrm{N}, \mathrm{P}$ and $\mathrm{K}$ @ 120:80:150 kg ha ${ }^{-1}$ at the time of planting and foliar application of $\mathrm{ZnSO}_{4} \& \mathrm{MnSO}_{4}$ as foliar at 50 days after planting i.e. $\mathrm{T}_{1}-(\mathrm{RDF})$ as basal at the time of planting; $\mathrm{T}_{2}-(\mathrm{RDF}$ and $25 \mathrm{~kg} \mathrm{ha}^{-1} \mathrm{ZnSO}_{4}$ as a basal) at time of planting; $\mathrm{T}_{3}-\left(\mathrm{RDF}\right.$ and $25 \mathrm{~kg} \mathrm{ha}^{-1} \mathrm{MnSO}_{4}$ as basal) at the time of planting; $\mathrm{T}_{4}-(\mathrm{RDF}$ and

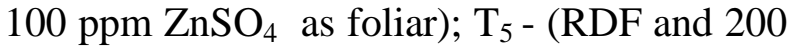
ppm $\mathrm{ZnSO}_{4}$ as foliar); $\mathrm{T}_{6}-(\mathrm{RDF}$ and 300 ppm $\mathrm{ZnSO}_{4}$ as foliar); $\mathrm{T}_{7}-$ (RDF and 100 ppm $\mathrm{MnSO}_{4}$ as foliar); $\mathrm{T}_{8}-(\mathrm{RDF}$ and 200 ppm $\mathrm{MnSO}_{4}$ as foliar) and $\mathrm{T}_{9}$ - (RDF and 300 ppm $\mathrm{MnSO}_{4}$ as foliar).

Foliar application of $\mathrm{ZnSO}_{4}$ and $\mathrm{MnSO}_{4}$ along with recommended dose of $\mathrm{N}$ : P: K @ 120:80:150 kgha ${ }^{-1}$ significantly increase the emergence percent of potato plant. Increase in concentration of these chemicals showed linear increase in plant emergence. Maximum emergence percent i.e. 93.65 and 93.35 were obtained at $300 \mathrm{ppm}$ concentration of $\mathrm{ZnSO}_{4}$ and $\mathrm{MnSO}_{4}$ applied as foliar at 50 days after planting. 
Table.1 Effect of basal and foliar application of $\mathrm{Zn}$ and $\mathrm{Mn}$ on growth parameters and yield of potato (Solanum tuberosum L.)

\begin{tabular}{|c|c|c|c|c|c|c|c|c|}
\hline \multirow[t]{2}{*}{ Treatments } & \multirow{2}{*}{$\begin{array}{c}\text { Emergence } \\
\text { Percentage } \\
\text { 30 DAS }\end{array}$} & \multicolumn{4}{|c|}{ Plant height (cm) } & \multirow{2}{*}{$\begin{array}{c}\text { Total no. of } \\
\text { tuber per } \\
\text { plant }(g)\end{array}$} & \multirow{2}{*}{$\begin{array}{l}\text { Weight of } \\
\text { tuber per } \\
\text { plant }(g)\end{array}$} & \multirow{2}{*}{$\begin{array}{l}\text { Yield of } \\
\text { tuber per } \\
\text { plot (kg.) }\end{array}$} \\
\hline & & 30 DAS & 45 DAS & 60 DAS & 75 DAS & & & \\
\hline $\mathbf{T}_{1}$ & 74.53 & 24.80 & 29.64 & 31.39 & 36.41 & 4.33 & 336.79 & 17.46 \\
\hline $\mathbf{T}_{2}$ & 75.91 & 25.23 & 31.36 & 33.06 & 38.52 & 5.67 & 352.02 & 21.39 \\
\hline $\mathbf{T}_{3}$ & 77.06 & 24.94 & 30.98 & 32.89 & 37.27 & 5.33 & 341.87 & 19.37 \\
\hline $\mathbf{T}_{4}$ & 85.65 & 25.22 & 33.75 & 36.42 & 38.59 & 6.33 & 380.22 & 22.57 \\
\hline $\mathbf{T}_{5}$ & 93.20 & 26.47 & 34.39 & 39.61 & 40.55 & 7.00 & 391.77 & 25.25 \\
\hline $\mathbf{T}_{6}$ & 93.65 & 29.53 & 35.05 & 42.07 & 43.14 & 8.00 & 435.12 & 26.98 \\
\hline $\mathbf{T}_{7}$ & 78.85 & 25.80 & 31.85 & 34.73 & 40.28 & 6.00 & 360.01 & 23.54 \\
\hline $\mathbf{T}_{8}$ & 88.35 & 25.88 & 33.62 & 38.97 & 40.33 & 6.67 & 384.90 & 24.37 \\
\hline $\mathbf{T}_{9}$ & 93.35 & 26.49 & 34.60 & 40.27 & 41.09 & 7.33 & 418.64 & 26.32 \\
\hline C.D. $(p=0.05)$ & 2.82 & 2.653 & 2.201 & 3.425 & 3.674 & 1.466 & 39.353 & 2.652 \\
\hline
\end{tabular}

Fig.1 Effect of basal and foliar application of $\mathrm{Zn}$ and $\mathrm{Mn}$ on number of haulms per plant of Potato (Solanum tuberosum L.)

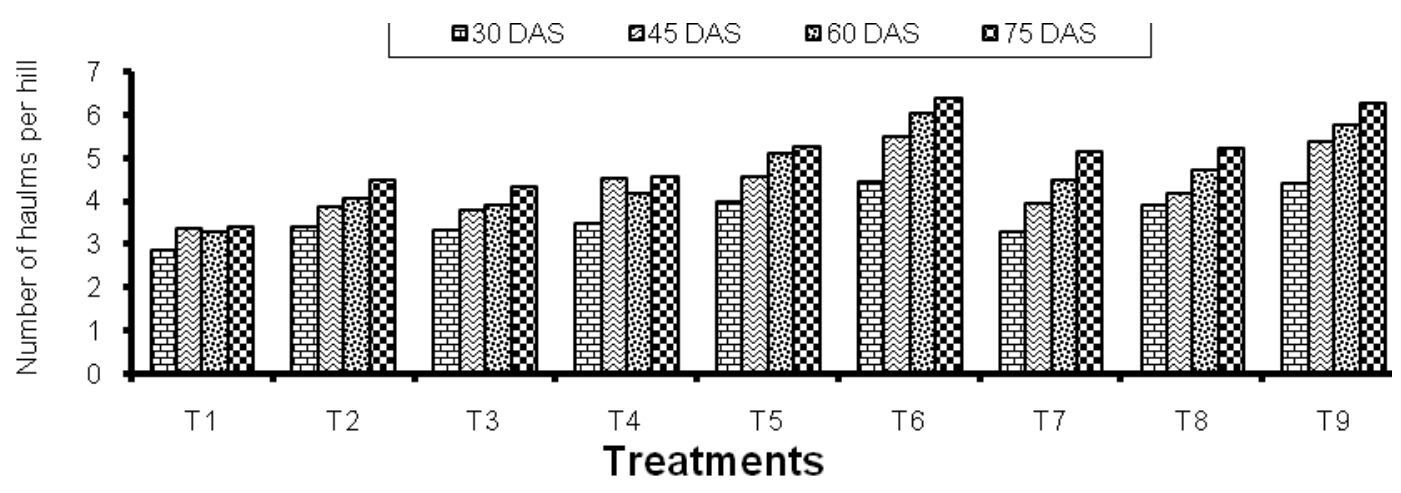

Fig.2 Effect on fresh weight of plant (g) at various stages as influenced by basal and foliar application of $\mathrm{ZnSO}_{4}$ and $\mathrm{MnSO}_{4}$

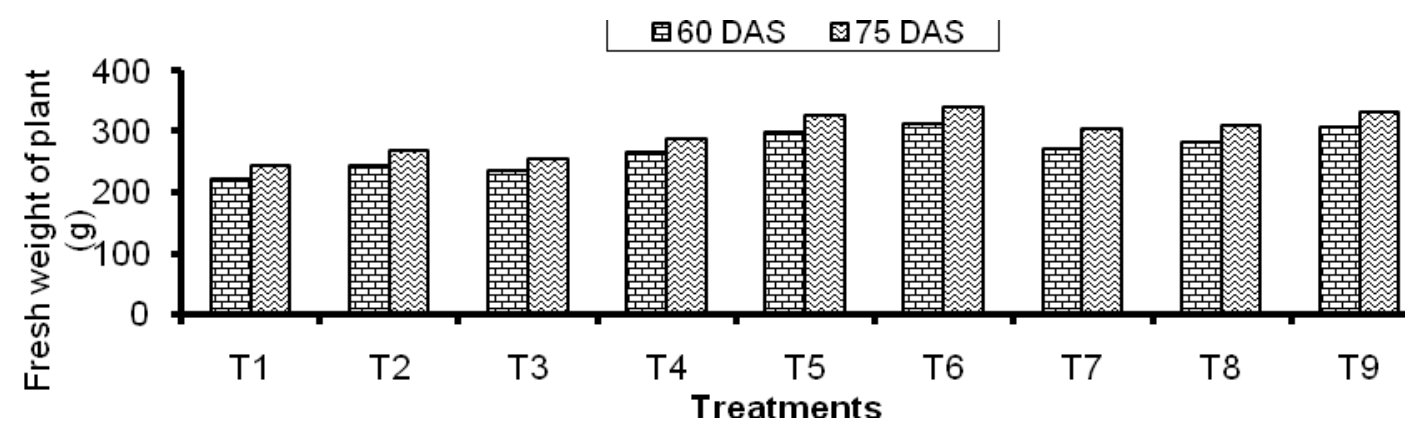


Fig.3 Effect on dry weight of plant (g) at various stages as influenced by basal and foliar application of $\mathrm{ZnSO}_{4}$ and $\mathrm{MnSO}_{4}$

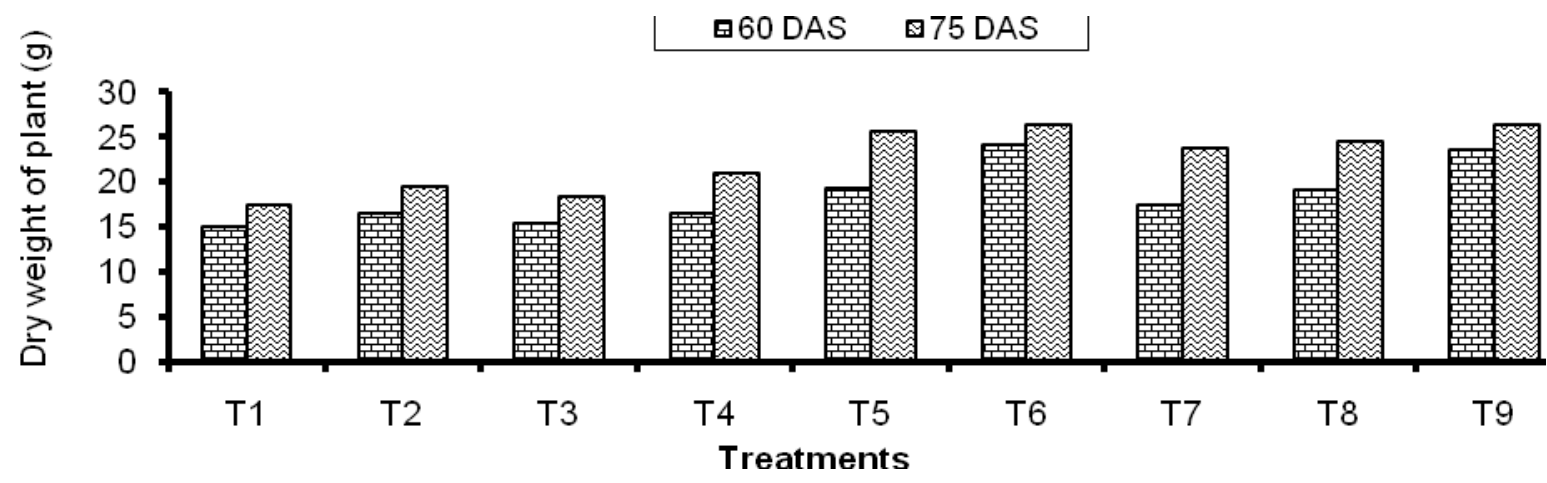

Basal application of $\mathrm{ZnSO}_{4}$ and $\mathrm{MnSO}_{4}$ did not showed significant effect on emergence.

Maximum plant height were increases

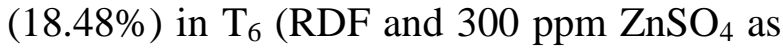
foliar) at 50 days after planting as compared with $\mathrm{T}_{1}$ (control) similarly number of haulms were increases $(88.23 \%)$ in $\mathrm{T}_{6}$ as compared with $\mathrm{T}_{1}$ (control) and maximum number of leaves per plant were increase $(27.93 \%)$ in $\mathrm{T}_{6}$ at par with $\mathrm{T}_{9}$ as compared with $\mathrm{T}_{1}$ (control). Plant height, number of haulms and number of leaves are morphological phenomenon which mainly control by hormonal balance towards a substantial increase in the cytokinine content and cytokinine/ABA ratio which lead to the cell division and cell elongation at and growing region of the plant, Barben et al., (2007) also investigated the plant height, number of hauls and number of leaves. The above result is similar to finding of Sayed Rohella et al., (2007). Different parameters are given in table 1 and Figure 1, $2 \& 3$.

The zinc and manganese basal and foliar application markedly increased the number of tubers per plant. Maximum percent increase (84.75) number of tubers per plant was observed in $\mathrm{T}_{6}$ followed by in $\mathrm{T}_{9}$ over control $\left(\mathrm{T}_{1}\right)$. Similarly, weight of tuber per plant was increases $(29.19 \%)$ in $\mathrm{T}_{6}$ followed by $\mathrm{T}_{9}$ as compared with $\mathrm{T}_{1}$ (control). Maximum yield of potato tuber per plot increases $(54.52 \%)$ in $\mathrm{T}_{6}$ followed by $\mathrm{T}_{9}$ as compared with $\mathrm{T}_{1}$ (control). Moreover, foliar application of zinc and manganese sulphate increases all plant characteristics relating to yield and quality of potato crop. Similar findings were also reported Alloway et al., (2004) and Hashemy et al., (1998).

On the present investigation we concluded that these micronutrients ( $\mathrm{Zn} \& \mathrm{Mn}$ ) are very necessary to improve the yield and quality of potato tuber crop. Further, linear increase an all parameters traits were observed with increase of concentration of these elements, thus its need further validation to include more concentration.

Maximum plant emergence percentage, plant height, number of haulms per hill and number of green leaves per plant was obtained in $\mathrm{T}_{6}$; $\mathrm{RDF}$ and $\mathrm{ZnSO}_{4} 300 \mathrm{ppm}$ as foliar), followed by $\mathrm{T}_{9}$; (RDF and $\mathrm{MnSO}_{4}$ applied as foliar) at after 50 days after planting respectively. Fresh and dry weight of plant was significantly increased in the $\mathrm{T}_{6}$; RDF and $\mathrm{ZnSO}_{4} 300$ ppm as foliar, followed by $\mathrm{T}_{9}$; $\mathrm{RDF}$ and $\mathrm{MnSO}_{4}$ $300 \mathrm{ppm}$ as foliar) at 50 days after planting respectively. The above results similar to findings of (Mosavi et al., 2007) and Parmar et al., (2016). 
Fresh and dry weight of plant was significantly increased in the $\mathrm{T}_{6}$; RDF and $\mathrm{ZnSO}_{4} 300 \mathrm{ppm}$ as foliar, followed by $\mathrm{T}_{9}$; $\mathrm{RDF}$ and $\mathrm{MnSO}_{4} 300 \mathrm{ppm}$ as foliar) at 50 days after planting respectively Rest the treatment did not showed significant effect on chlorophyll content at all crop growth stages. Foliar application of $\mathrm{ZnSO}_{4}$ and $\mathrm{MnSO}_{4}$ @ 300 ppm along with RDF applied as basal significantly increased $\mathrm{T}_{6} ; \mathrm{RDF}$ and $\mathrm{ZnSO}_{4}$ $300 \mathrm{ppm}$ as foliar) at 50 days after planting.

The zinc and manganese basal and foliar application markedly increased the number of tubers per plant. Maximum percent increase (84.75) number of tubers per plant was observed in $\mathrm{T}_{6}$ followed by in $\mathrm{T}_{9}$ over control $\left(\mathrm{T}_{1}\right)$. Similarly, weight of tuber per plant was increases $(29.19 \%)$ in $\mathrm{T}_{6}$ followed by $\mathrm{T}_{9}$ as compared with $\mathrm{T}_{1}$ (control). Maximum yield of potato tuber per plot increases $(54.52 \%)$ in $\mathrm{T}_{6}$ followed by $\mathrm{T}_{9}$ as compared with $\mathrm{T}_{1}$ (control). Moreover, foliar application of zinc and manganese sulphate increases all plant characteristics relating to yield and quality of potato crop. Similar findings were also reported Alloway et al., (2004) and Hashemy et al., (1998).

On the present investigation we concluded that these micronutrients ( $\mathrm{Zn}$ and $\mathrm{Mn}$ ) are very necessary to improve the yield and quality of potato tuber crop. Further, linear increase an all parameters traits were observed with increase of concentration of these elements, thus its need further validation to include more concentration.

\section{References}

Alloway, B.J. (2004). Zinc in Soils and Crop Nutrition. 1st Edn., International Zinc Association (IZA), Brussels, Belgium, pp: 128.

Barben, S.A., Nichols, B.A. and Ellsworth, J.W. (2007). Phosphorus and Zinc interactions in potato Western Nutrient Management Conference Vol. 7. Salt Lake City, UT. Brigham Young University, Provo, UT Wilbur-Ellis, Pasco, WA.

Grotz, N. and Guerinot, M.L. (2006). Molecular aspects of $\mathrm{Cu}, \mathrm{Fe}$ and $\mathrm{Zn}$ homestasis in plants. Biochimicaet Biophysica Acta 1763 (7): 595-608.

Mousavi, S.R., Galavi, M. and Ahmadvand, G. (2007). Effect of zinc and manganese foliar application on yield, quality and enrichment on potato (Solanum tuberosum L.) Faisalabad, Pakistan. Asian Journal of Plant Sciences 6 1256-1260.

Parmar, Mehul., Nndre, B.M. and Pawar, Yogesh (2016). Influence of foliar supplementation of zinc and manganese on yield and quality of potato, (Solanum tuberosum L.) International Journal of Farm Sciences 6(1):69-73.

Hashemy, M.K., M.J. Malakoty and Tabatabaey, V.S.J. (1998). Effect of foliar application of micronutrients in quality and quantity potato crop in Eastern Azarbyjan Province J. Sci. Res. Soil Water, 12: 4455.

Sayed Roholla Mousavi, Mohammad Galavi and Ahmadvand. (2007). Effect of Zinc and Manganese Foliar Application on Yield, Quality and Enrichment on Potato (Solanum tuberosum L.) Asian Journal of Plant Sciences, 6: 1256-1260.

\section{How to cite this article:}

Madhukar Singh, Alok Kumar, Sanjay Kumar Tripathi, Subhash Kumar and Singh, A.K. 2018. Effect of Foliar Application of Zinc and Manganese on Growth Parameters and Yield of Potato (Solanum tuberosum L.). Int.J.Curr.Microbiol.App.Sci. 7(07): 1390-1394. doi: https://doi.org/10.20546/ijcmas.2018.707.165 